Summary: Every article should have a short summary (not more than 250 words) complete in itself and understandable without reference to the paper. The summary will be printed at the beginning of the paper.

References: Only papers closely related to the author's work should be referred to; exhaustive lists should be avoided. Bibliographical details should be in the following order: author's name, initials, year, title of paper, title of journal (abbreviated according to the World List of Scientific Periodicals), volume of journal, first and last page of paper. References should be listed in alphabetical order. When abstracts are referred to, the page reference should be followed by (Abstr.).

\title{
Examples:
}

Blaxter, K. L. and Wilson, R. S. 1962. The voluntary intake of roughages by steers. Anim. Prod. 4: 351-358.

Hammond, J. 1932. Growth and the Development of Mutton Qualities in the Sheep. Oliver and Boyd, Edinburgh.

In the text, references should be made by giving author and year; at the first mention all authors should be named, thereafter the first author followed by $e t$ al. should be used for papers with more than two authors.

Proofs are supplied once and must be returned corrected to the Editors within seven days. Only essential corrections should be made.

Reprints: Twenty-five reprints of each paper will be supplied free to authors on request. Further copies may be purchased if the order is sent at the proof stage.

Animal Production is published six times a year in two volumes. Annual subscription is $£ 9.00$ (or $\$ 25.00$ in the U.S.A. and Canada) and the price for a single part is $£ 1.75$ (or $\$ 6.00$ ) net.

Proceedings of the British Society of Animal Production recommenced annual publication as a new series in 1972. Annual subscription is $£ 1.75$ ( $\$ 6.00$ U.S. and Canada) or available with a joint subscription to Animal Production at $£ 10.00$ (\$28.00).

Business matters, including regular subscriptions and sales (current and back numbers of the Journal and the Proceedings) should be addressed to Longman Group, Journals Division, 43/45 Annandale Street, Edinburgh EH7 4AT.

\section{Senior Editor}

Gerald Wiener, A.R.C. Animal Breeding Research Organisation.

\section{Editors}

J. F. D. Greenhalgh, Rowett Research Institute.

W. G. HiLl, Institute of Animal Genetics.

L. E. Mount, A.R.C. Institute of Animal Physiology.

J. A. F. Rook, Hannah Dairy Research Institute.

J. C. TAYLER, Grassland Research Institute. 


\section{CONTENTS}

Verstegen, M. W. A. and VAN DER Hel, W. The effects of temperature and type of floor on metabolic rate and effective critical temperature in groups of growing pigs

SLEE, J. Cold-induced inhibition of thermal panting in shorn sheep. 3. Effect of previous habituation to cold

STEPHENS, D. B. Studies on the effect of social environment on the behaviour and growth rates of artificially-reared British Friesian male calves

Willis, M. B. and Wilson, A. Comparative reproductive performance of Brahman and Santa Gertrudis cattle in a hot humid environment. 1. Fertility and descriptive statistics .

Wilson, A. and Willis, M. B. Comparative reproductive performance of Brahman and Santa Gertrudis cattle in a hot humid environment. 2. Factors affecting calving interval

McCullough, T. A. The effect of different proportions of dried grass and concentrates in the diet on voluntary intake and performance of calves

BAR-ANAN, R. and SACKS, J. M. Sire evaluation and estimation of genetic gain in Israeli dairy herds

Levy, D., Holzer, Z., Neumark, H. and Amir, S. The effects of dietary energy content and level of feeding on the growth of Israeli-Friesian intact male cattle

Fraser, C. and Ørskov, E. R. Cereal processing and food utilization by sheep. 1. The effect of processing on utilization of barley by earlyweaned lambs

Ørskov, E. R., Fraser, C. and McHattie, I. Cereal processing and food utilization by sheep. 2. A note on the effect of feeding unprocessed barley, maize, oats and wheat on food utilization by early-weaned lambs

ShEVAH, Y. A note on the use of dexamethasone for inducement of parturition of Finn $\times$ Dorset ewes

Mines, C. A. and Fursey, G. A. J. A note on the velocity of ultrasound in living tissue

Hegarty, P. V. J. A note on the use of sarcomere length measurements as predictors of longitudinal growth in skeletal muscles . . . .

FORDYCE, J. and KAY, M. A note on the recovery of polyethylene particles from faeces and rumen contents of steers.

FORDYCE, J. and KAY, M. A note on the effect of polyethylene particles on rumen metabolism of steers 